\title{
Characterization and Classification of Halomorphic Soils in the Semiarid Region of Northeastern Brazil
}

\author{
Luiz Guilherme Medeiros Pessoa ${ }^{1}$, Maria Betânia Galvão dos Santos Freire ${ }^{2}$, José Coelho de Araújo Filho ${ }^{3}$, \\ Patrícia Ribeiros dos Santos ${ }^{4}$, Márcio Fléquisson Alves Miranda ${ }^{5}$ \& Fernando José Freire ${ }^{2}$ \\ ${ }^{1}$ Department of Plant Production, Federal Rural University of Pernambuco, Serra Talhada, Pernambuco, Brazil \\ ${ }^{2}$ Agronomy Department, Federal Rural University of Pernambuco, Recife, Pernambuco, Brazil \\ ${ }^{3}$ Brazilian Agricultural Research Corporation, UEP Recife, Recife, Pernambuco, Brazil \\ ${ }^{4}$ Federal Institute of Pernambuco, Campus Barreiros, Barreiros, Pernambuco, Brazil \\ ${ }^{5}$ Federal Institute of Pernambuco, Campus Vitória de Santo Antão, Vitória de Santo Antão, Pernambuco, Brazil \\ Correspondence: Luiz Guilherme Medeiros Pessoa, Department of Plant Production, Federal Rural University of \\ Pernambuco, Avenida Gregório Ferraz Nogueira, S/N, 56909-535, Serra Talhada, PE, Brazil. Tel: \\ 55-87-3929-3026. E-mail: pessoa.lgm@gmail.com
}

Received: December 19, 2018

Accepted: January 20, 2019 Online Published: March 15, 2019

doi:10.5539/jas.v11n4p405

URL: https://doi.org/10.5539/jas.v11n4p405

\begin{abstract}
The properties of halomorphic soils are controlled by the presence of either soluble salts, exchangeable sodium or both, and it is important to know and understand these properties in order to reforest and/or recover the soils. The objective of this study was to characterize and classify halomorphic soils from the semiarid region of Northeast Brazil. Four profiles of halomorphic soils were studied, which were described morphologically and the samples were collected from all soil horizons. Physical and chemical analyzes of the soils were carried out for classification purposes, as well as geochemical speciation of the soluble salts. According to the results, P1 and P3 were classified as Fluvisols, and P2 and P4 as Cambisols. It was observed that the studied soil profiles have the predominance of fine particles, which prevents the leaching and subsequent removal of salts from the soil profile. Soils presented high levels of exchangeable sodium, characterizing them as sodium solids throughout the profile. Ionic speciation analysis indicated the predominance of free forms of $\mathrm{Ca}^{2+}, \mathrm{Mg}^{2+}, \mathrm{Na}^{+}$and $\mathrm{K}^{+}, \mathrm{HCO}_{3}^{-}$, $\mathrm{Cl}^{-}$and $\mathrm{SO}_{4}{ }^{2-}$ and combinations of calcium, magnesium and sodium chloride and sulfate salts. Thus, it was possible to conclude that the studied halomorphic soils presented high levels of degradation by salts and sodium and that these types of soils are strongly related to the Fluvisols and Cambisols.
\end{abstract}

Keywords: saline soils, sodic soils, soil degradation, ionic salt speciation

\section{Introduction}

The properties of halomorphic soils are controlled by the presence of either soluble salts, exchangeable sodium or both. Although difficult to estimate precisely, globally the total area of salinized soils is increasing, especially in heavily irrigated areas, and is estimated to cover over 400 million hectares, which more than $6 \%$ of the world land area (Arora, 2017). Additionally, approximately $20 \%$ of irrigated land, responsible for one-third of the world's food production, is affected by salts and sodium (Machado \& Serralheiro, 2017).

Salts in soils are often derived from geological formations featuring shale, marl, limestone, sylvite, gypsum, and halite (Aldabaa et al., 2015). Moreover, salts can be transported to the soil surface by capillary action from brackish water tables where it accumulates due to evaporation. Salts can also accumulate as a result of anthropogenic activities such as fertilization or irrigation especially with saline water. Additionally, the process of soil salinization can be accelerated by climate change, excessive use of groundwater and massive introduction of irrigation associated with intensive farming and poor drainage (Machado \& Serralheiro, 2017).

Salt stress directly affects plant growth due to increased soil osmotic pressure, which causes toxicity of specific-ions, and nutritional imbalances. Moreover, soil salinity can also indirectly affect plant growth due to the effect of sodium on the degradation of the soil's physical condition and by increasing soil $\mathrm{pH}$. Decreases in plant biomass, leaf area, number of leaves, stem diameter, and plant height have been observed in different 
vegetable crops under salt stress in several studies found in existing literature (Gomes et al., 2011; Lopes et al., 2017; de Andrade et al., 2018).

The problem of salinity in Brazil is especially severe in the semiarid region in the Northeast where the majority of salinized soils are found, although other areas in the Amazon Region and Northern Minas Gerais are also affected. According to surveys published by the "National Survey and Soil Conservation Service" (Serviço Nacional de Levantamento e Conservação de Solos-SNLCS) (Pereira et al., 1982), over 9.1 million hectares of salt affected soils have been identified in the Northeast alone. This occurs mainly due to factors related to climatic conditions in the region, where potential evapotranspiration rates exceed precipitation (typical of conditions in arid and semiarid regions) and deficient drainage conditions. Under these conditions, some soils tend to be more prone to the phenomenon of salinization, and this variable susceptibility among the soils largely depends on their physical, chemical and mineralogical properties.

Luvisols, Ferralsols and Podzols, by the very nature of the pedogenetic processes involved in their formation which is marked by intense chemical weathering and leaching, do not present salinity or sodicity in normal conditions. Problems of high levels of salinity and sodicity are closely related to the formation of soil that has suborders and great groups formed under conditions of deficient drainage in semiarid regions, as Fluvisols, Vertisols, Cambisols, Planosols and Gleysols. The remaining orders of the Brazilian System of Soil Classification, including Regosols, Arenosols, Chernozems, Planosols, Nitisols and Plinthosols as well as large groups of Fluvisols, Vertisols, Cambisols, Gleysols and Histosols present salinity and sodicity to a moderate degree (Ribeiro et al., 2003). Thus, of the thirteen orders of soil in the Brazilian System of Soil Classification, ten orders are prone to problems of salinization and sodification, which demonstrates the importance of this issue for soil scientists in Brazil.

The level of degradation by salinity and/or sodicity in halomorphic soil is sufficiently elevated such that these soils are rarely used for agriculture. Thus, it is important to identify the soil degradation level caused by salinity/sodicity in order to establish effective plans for the recovery and management of these soils. This would be of great importance for reforestation efforts in these areas. In this context, based on the hypothesis that salts vary in level and type according to each soil type's susceptibility to halomorphism and with the goal of contributing to the understanding of the dynamics of salts in these soils, the purpose of this study is the characterization and classification of Halomorphic soils found in the semiarid region of the state of Pernambuco, Brazil.

\section{Method}

\subsection{Study Area}

The study area consisted of three contiguous watersheds (Moxotó, Pajeú and Brígida) within the semiarid region of Pernambuco State in Northeastern Brazil (Figure 1). These watersheds cover a total area of about $45.000 \mathrm{~km}^{2}$. This region is characterized by low rainfall (averaging about $600 \mathrm{~mm} /$ year) and high potential evapotranspiration (exceeding $2000 \mathrm{~mm} /$ year). Average annual temperatures range from $23^{\circ} \mathrm{C}$ to $27^{\circ} \mathrm{C}$.

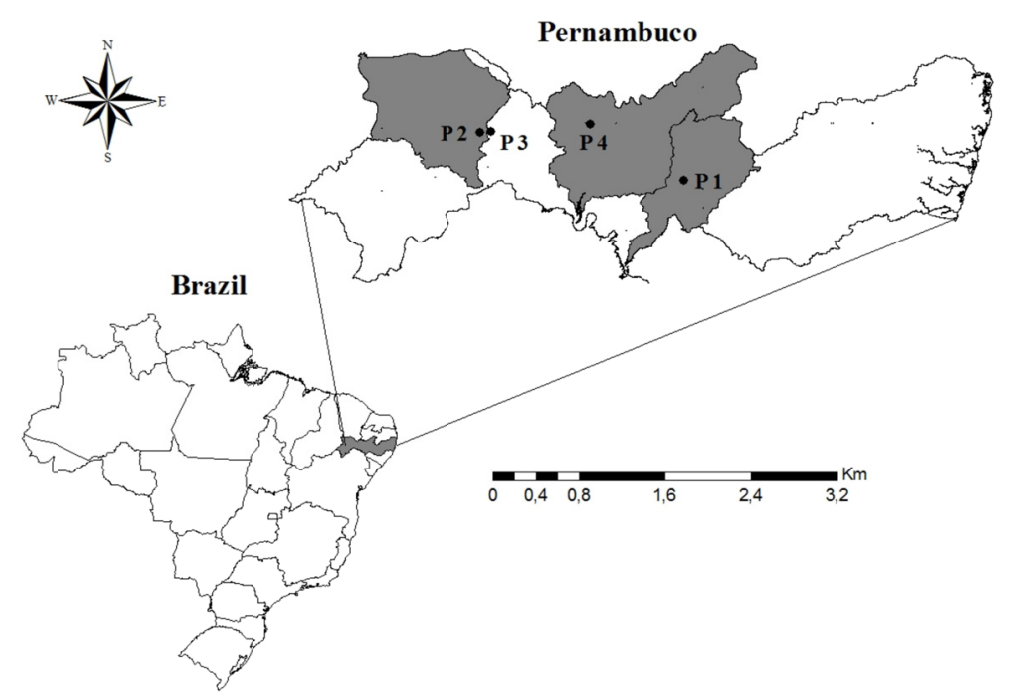

Figure 1. Study watersheds and soil profiles map from the state of Pernambuco, Brazil 
The climate is characterized by distinct wet and dry seasons, with rain occurring mostly from May until August. Rainfall is exceedingly variable, in terms of both volume and time, and multiple-year droughts are common (Sampaio, 1995). The prevalent vegetation type is Caatinga shrubland, a semi-deciduous thorn forest that covers an extensive portion of northeastern Brazil (de Albuquerque et al., 2012). Irrigated agriculture is typically carried out along the river valleys, and it is in these valleys that the saline soils are concentrated. The extensive soil salinization occurs mainly as a result of poor irrigation management utilizing low-quality water for irrigation (Ferreira et al., 2012).

\subsection{Soil Profile Sampling}

Soil profile 1 (P1) was collected in the municipality of Ibimirim, located in the Moxoto watershed, at the coordinates Lat: $-8^{\circ} 32^{\prime} 10^{\prime \prime}$; Long: $-37^{\circ} 40^{\prime} 11^{\prime \prime}$, at an altitude of $431 \mathrm{~m}$. The soil had been uncovered and the little local vegetation present consisted exclusively of halophytes, which are indicative of saline environments. Soil profile 2 (P2) was collected in the municipality of Parnamirim, situated in the Brígida watershed, at coordinates Lat: - $8^{\circ} 5^{\prime} 41^{\prime \prime}$; Long: $-39^{\circ} 34^{\prime} 21^{\prime \prime}$, at an altitude of $392 \mathrm{~m}$. The soil was also uncovered and presented with local vegetation consists predominantly of halophytes. Soil profile 3 (P3) was also collected in the municipality of Parnamirim, at coordinates Lat: $-8^{\circ} 10^{\prime} 9^{\prime \prime}$; Long: $-39^{\circ} 40^{\prime} 21^{\prime \prime}$. The soil was mostly uncovered and presented a local vegetation consisting predominantly of halophytes and some small trees. Soil profile 4 (P4) was collected in Serra Talhada, located in the Pajeú watershed, at coordinates Lat: - $7^{\circ} 55^{\prime} 4^{\prime \prime}$; Long: $-38^{\circ} 19^{\prime} 10^{\prime \prime}$, at an altitude of $429 \mathrm{~m}$. As in the other cases, the ground had also been uncovered with local vegetation consisting solely of halophytes.

The descriptions of the profiles and sample collection were developed according to the recommendations of the Handbook of Soil Description and Field Soil Collection (Santos et al., 2005). Disturbed samples were collected from all soil profiles and soil samples were collected from the horizons in each soil profile. After collection, the disturbed samples collected in the horizons of soil profiles were air dried and initially sieved in a $2 \mathrm{~mm}$ mesh, for physical and chemical analysis characterization.

\subsection{Physical Analysis}

Physical analysis determined content levels for sand, silt and clay, including water-dispersible clay, by sieving and sedimentation (Ruiz, 2005). The sand content was determined for thick sand (particle size diameter between 2 and $0.2 \mathrm{~mm}$ ) and fine sand (particle size diameter between 0.2 and $0.05 \mathrm{~mm}$ ). The bulk density was analyzed for an unmixed sample and soil particle density was analyzed by volumetric flask, according to Embrapa (1997).

Total porosity was calculated for bulk density and particle density soil data. The degree of flocculation was calculated for total clay and water-dispersible clay data. The silt/clay relation was obtained by the separation of the silt and clay contents.

\subsection{Chemical Analysis}

For the evaluation of the chemical attributes, soil samples were submitted to soluble and exchangeable element analysis, according to Richards (1954). For the saturation extract were obtained the electrical conductivity (EC at $25^{\circ} \mathrm{C}$ ) and $\mathrm{pH}$. For soluble cations, $\mathrm{Ca}^{2+}$ and $\mathrm{Mg}^{2+}$ were obtained by atomic absorption spectrophotometry and $\mathrm{Na}^{+}$and $\mathrm{K}^{+}$by flame emission photometry. The anions $\mathrm{Cl}^{-}, \mathrm{CO}_{3}{ }^{2-}$ and $\mathrm{HCO}_{3}{ }^{-}$were obtained by titration and $\mathrm{SO}_{4}{ }^{2-}$ by colorimetry.

For the soil, was measured $\mathrm{pH}\left(1: 2.5\right.$-water and $\left.\mathrm{KCl} 1 \mathrm{~mol} \mathrm{~L}^{-1}\right)$ and were determined the exchangeable cations $\mathrm{Ca}^{2+}, \mathrm{Mg}^{2+}, \mathrm{K}^{+}$and $\mathrm{Na}^{+}$, via extraction with ammonium acetate solution $1 \mathrm{~mol} \mathrm{~L}^{-1}$. The $\Delta \mathrm{pH}$ was obtained by the difference between $\mathrm{pH}\left(\mathrm{KCl} 1 \mathrm{~mol} \mathrm{~L}^{-1}\right)-\mathrm{pH}$ (water). $\mathrm{Ca}^{2+}$ and $\mathrm{Mg}^{2+}$ were determined by atomic absorption spectrophotometry and $\mathrm{Na}^{+}$and $\mathrm{K}^{+}$by flame emission photometry. The cation exchange capacity (CEC) was determined by the method of sodium acetate and ammonium acetate $1 \mathrm{~mol} \mathrm{~L}^{-1}$ (Richards, 1954). The organic carbon content was obtained according to Walkley-Black method, modified by Tedesco et al. (1995). With the results of analyzes, the exchangeable sodium percentage (ESP) was determined, according to Richards (1954).

\subsection{Data Analysis}

Physical and chemical (exchangeable and soluble) variables were described through mean values, for each studied soil profile. With the values of $\mathrm{pH}$, cation and anion levels in the saturation extract of soil, in each horizon for all soil profiles studied, we performed chemical speciation of ions with the Visual Minteq 3.0 software. Chemical speciation describes the composition of an aqueous solution. The significance of chemical speciation for the studies in soils is its usefulness as a tool for the interpretation of toxicity of chemical compounds. Thus, through this analysis it was possible to have a knowledge of which species dominate the chemical composition of each soil solution among the soil profiles studied. 


\section{Results and Discussion}

The soils studied have profiles with characteristic features of orders of Fluvisols and Cambisols, which may indicate a strong connection between these soil orders and salinity/sodicity problems in the semiarid region of Pernambuco. Soil profile 1, located in the municipality of Ibimirim (Moxotó watershed), presented the sequence of horizons Apz1-Apz2-2Cz1-2Cz2-2Cvz1-2Cvz2 (Table 1), and a depth greater than $160 \mathrm{~cm}$. This profile was classified, according to the Brazilian System of Soil Classification-SiBCS (Embrapa, 2013), as NEOSSOLO FLÚVICO Sódico sálico (Fluvisol).

Table 1. Physical attributes of the soil profiles studied

\begin{tabular}{|c|c|c|c|c|c|c|c|c|c|c|c|}
\hline \multirow{2}{*}{ Horizon } & \multirow{2}{*}{ Depth } & \multicolumn{2}{|c|}{ Sand } & \multirow{2}{*}{ Silt } & \multirow{2}{*}{ Clay } & \multirow{2}{*}{ WDC } & \multirow{2}{*}{ FI } & \multirow{2}{*}{ Silt/Clay } & \multirow{2}{*}{ SBD } & \multirow{2}{*}{ SPD } & \multirow{2}{*}{ Porosity } \\
\hline & & Coarse & Fine & & & & & & & & \\
\hline & $\mathrm{cm}$ & \multicolumn{3}{|c|}{ - $\mathrm{g} \mathrm{kg}^{-1}$} & $---\cdot-$ & -------- & \multicolumn{2}{|l|}{$\%$} & \multicolumn{2}{|c|}{$--\mathrm{mg} \mathrm{m}^{-3}--$} & $\%$ \\
\hline \multicolumn{12}{|c|}{ P1_Fluvisol (NEOSSOLO FLÚVICO sódico sálico) } \\
\hline Apz1 & $0-10$ & 25.6 & 41.4 & 248.6 & 684.4 & 94.4 & 86.21 & 0.36 & 1.65 & 2.55 & 35.29 \\
\hline Apz2 & $10-28$ & 6.6 & 99.8 & 139.2 & 754.4 & 384.4 & 49.05 & 0.18 & 1.59 & 2.45 & 35.10 \\
\hline $2 \mathrm{Cz} 1$ & $28-52$ & 17.6 & 30.6 & 277.4 & 674.4 & 574.4 & 14.83 & 0.41 & 1.63 & 2.60 & 37.31 \\
\hline $2 \mathrm{Cz} 2$ & $52-82$ & 17.4 & 18.6 & 269.6 & 694.4 & 634.4 & 8.64 & 0.39 & 1.57 & 2.44 & 35.66 \\
\hline 2Cgvz1 & $82-130$ & 7.6 & 13.6 & 204.4 & 774.4 & 644.4 & 16.79 & 0.26 & 1.55 & 2.62 & 40.84 \\
\hline 2Cgvz2 & $130-160$ & 7.6 & 18.6 & 239.4 & 734.4 & 614.4 & 16.34 & 0.33 & 1.56 & 2.68 & 41.79 \\
\hline \multicolumn{12}{|c|}{ P2-Cambisol (CAMBISSOLO FLUUVICO sódico salino) } \\
\hline Ap1 & $0-5$ & 27.4 & 406.4 & 351.8 & 214.4 & 194.4 & 9.33 & 1.64 & 1.65 & 2.66 & 37.97 \\
\hline $2 \mathrm{Ap} 2$ & $5-20$ & 17.6 & 380.6 & 287.4 & 314.4 & 274.4 & 12.72 & 0.91 & 1.69 & 2.68 & 36.94 \\
\hline 2Bi & $20-48$ & 6.0 & 235.6 & 424.0 & 334.4 & 260.8 & 22.01 & 1.27 & 1.53 & 2.78 & 44.96 \\
\hline 2BC & $48-85$ & 7.4 & 263.8 & 404.4 & 324.4 & 267.2 & 17.63 & 1.25 & 1.57 & 2.82 & 44.33 \\
\hline $2 \mathrm{C} 1$ & $85-120$ & 8.4 & 316.0 & 391.2 & 284.4 & 147.2 & 48.24 & 1.38 & 1.60 & 2.44 & 34.43 \\
\hline $3 \mathrm{C} 2$ & $120-190$ & 26.0 & 242.6 & 407.0 & 324.4 & 267.2 & 17.63 & 1.25 & 1.65 & 2.49 & 33.73 \\
\hline \multicolumn{12}{|c|}{ P3-Fluvisol (NEOSSOLO FLUUVICO sódico sálico) } \\
\hline Ap & $0-10$ & 25.8 & 186.2 & 613.6 & 174.4 & 67.2 & 61.47 & 3.52 & 1.65 & 2.73 & 39.56 \\
\hline $\mathrm{Cv}$ & $10-40$ & 21.4 & 126.6 & 397.6 & 454.4 & 363.6 & 19.98 & 0.87 & 1.67 & 2.89 & 42.21 \\
\hline $2 \mathrm{C}$ & $40-75$ & 9.8 & 119.4 & 456.4 & 414.4 & 353.6 & 14.67 & 1.10 & 1.66 & 2.46 & 32.52 \\
\hline $3 \mathrm{Cg} 1$ & $75-120$ & 6.0 & 270.0 & 429.6 & 294.4 & 240.0 & 18.48 & 1.46 & 1.61 & 2.74 & 41.24 \\
\hline $4 \mathrm{Cg} 2$ & $120-150$ & 31.8 & 801.0 & 72.8 & 94.4 & 60.0 & 36.44 & 0.77 & 1.59 & 2.74 & 41.97 \\
\hline \multicolumn{12}{|c|}{ P4-Cambisol (CAMBISSOLO FLUUVICO sódico salino) } \\
\hline Ap & $0-12$ & 65.2 & 252.2 & 428.2 & 254.4 & 216.4 & 14.94 & 1.68 & 1.56 & 2.44 & 36.07 \\
\hline BA & $12-26$ & 50.4 & 229.6 & 445.6 & 274.4 & 240.0 & 12.54 & 1.62 & 1.56 & 2.63 & 40.68 \\
\hline $\mathrm{Bi}$ & $26-60$ & 98.0 & 261.2 & 306.4 & 334.4 & 280.0 & 16.27 & 0.92 & 1.60 & 2.74 & 41.61 \\
\hline $\mathrm{C} 1$ & $60-100$ & 70.2 & 267.0 & 368.4 & 294.4 & 247.2 & 16.03 & 1.25 & 1.55 & 2.41 & 35.68 \\
\hline $\mathrm{C} 2$ & $100-160$ & 41.4 & 250.0 & 374.2 & 334.4 & 290.0 & 13.28 & 1.12 & 1.60 & 2.67 & 40.07 \\
\hline $2 \mathrm{C} 3$ & $160-200$ & 167.6 & 264.8 & 243.2 & 324.4 & 260.0 & 19.85 & 0.75 & 1.55 & 2.67 & 41.95 \\
\hline
\end{tabular}

Note. $\mathrm{WDC}=$ water dispersible clay. $\mathrm{FI}=$ flocculation index. $\mathrm{SBD}=$ soil bulk density. $\mathrm{SPD}=$ soil particle density.

Soil profile 2, located in the municipality of Parnamirim (Brígida watershed), and presented the sequence of horizons: Ap1-2Ap2-2Bi-2BC-2C1-3C2 (Table 1) with a depth of $190 \mathrm{~cm}$, is classified as a CAMBISSOLO FLÚVICO Sódico salino (Embrapa, 2013) (Cambisol). The soil profile 3, located in the municipality of Parnamirim (Brígida watershed), presented the sequence of horizons $\mathrm{Ap}-\mathrm{Cv}-2 \mathrm{C}-3 \mathrm{Cg} 1-4 \mathrm{Cg} 2$ (Table 1), with a depth of $150 \mathrm{~cm}$, classified as NEOSSOLO FLÚVICO Sódico sálico (Embrapa, 2013) (Fluvisol). Profile 4, located in the municipality of Serra Talhada (Pajeú watershed), had the sequence of horizons: $\mathrm{Ap}-\mathrm{BA}-\mathrm{Bi}-\mathrm{C} 1-\mathrm{C} 2-2 \mathrm{C} 3$ (Table 1), and a depth greater than $200 \mathrm{~cm}$, is also classified as CAMBISSOLO FLÚVICO Sódico salino (Embrapa, 2013) (Cambisol). 
The results of the physical attributes assessed in this study are shown in Table 1. Considering all horizons, the contents of the coarse sand fraction varied from 6.6 to $25.6 \mathrm{~g} \mathrm{~kg}^{-1}$ in P1; from 6.0 to $27.4 \mathrm{~g} \mathrm{~kg}^{-1}$ in P2; 6.0 to 31.8 $\mathrm{g} \mathrm{kg}^{-1}$ in P3; and from 41.4 to $167.6 \mathrm{~g} \mathrm{~kg}^{-1}$ in P4. For the fine sand fraction, the variation was from 13.6 to 99.8 $\mathrm{kg}^{-1} \mathrm{~g}$ in P1; 235.6 to $406.6 \mathrm{~g} \mathrm{~kg}^{-1}$ in P2; 119.4 to $801.0 \mathrm{~g} \mathrm{~kg}^{-1}$ in P3; and 229.6 to $267.0 \mathrm{~g} \mathrm{~kg}^{-1}$ in P4. The silt fraction ranged from 139.2 to $277.4 \mathrm{~g} \mathrm{~kg}^{-1}$ in $\mathrm{P} 1$; from 287.4 to $407.0 \mathrm{~g} \mathrm{~kg}^{-1}$ in $\mathrm{P} 2$; from 72.8 to $613.6 \mathrm{~g} \mathrm{~kg}^{-1} \mathrm{in}^{-1}$ $\mathrm{P} 3$; and 243.2 to $445.6 \mathrm{~g} \mathrm{~kg}^{-1}$ in P4. In the clay fraction, the variation was from 684.4 to $774.4 \mathrm{~g} \mathrm{~kg}^{-1}$ in P1; from 214.4 to $334.4 \mathrm{~g} \mathrm{~kg}^{-1}$ in P2; from 94.4 to $454.4 \mathrm{~g} \mathrm{~kg}^{-1}$ in P3; and 254.4 to $334.4 \mathrm{~g} \mathrm{~kg}^{-1}$ in P4.

Regarding the soil texture, there was a predominance of silt fraction in soil profiles P2, P3 and P4, while P1 presented clay as the dominant fraction. Moreover, the fine sand fraction is predominant in relation to coarse sand. This property can lead to a specific limitation on its soil in terms of water infiltration capacity, because fine sand can usually cause declining of macropores (Lepsch, 2002).

Thus, it is noted that the studied soil profiles have a fine particle size distribution, which hinders the leaching and subsequent removal of salts in the soil profile. Additionally, the environmental conditions of intense evaporation rates and low precipitation rates favor the accumulation of salts in the soil profile. This indicates that the occurrence of saline or saline-sodic soils most likely occur in semiarid regions, due to the non-removal salts. Soils with exclusively exchangeable sodium problems, and no salts, must occur in conditions where the parent material is originally rich in sodium.

The water dispersible clay values were relatively high in all studied profiles, where P1 showed higher values of water-dispersible clay, as compared to the other profiles analyzed (Table 1). In this soil profile, the water-dispersible clay increased in respect to depth. This was reflected in a reduction in flocculation rate in respect to depth, which in turn presents the contrary behavior of water-dispersible clay. In the other soil profiles we observed the heterogeneity of water dispersible clay values with depth, and consequently, the flocculation rates.

The silt/clay ratio showed different values between the soils, but showed higher values of this relationship to the Cambisols (P2 and P4) than to Fluvisols (P1 and P3), indicating a lesser degree of development of these soil profiles. According Jacomine (2005), the silt/clay ratio is used as an index for the indication of the degree of weathering of the soil; thus, the higher the value of this ratio indicates less weathered soil.

The bulk density values, in general, were high and showed little variation in all studied soil profiles, indicating a degree of compaction of these soils. Particle density showed similar values in all soil profiles, showing the presence of particles of the same mineral composition. Thus, the high bulk density values influenced the low porosity values, which ranged from 35.10 to $44.96 \%$. This reflects soil profiles with physical conditions that hinder the movement of water within the soil, not only due to textural material which is predominantly thin, but also the low porosity of these soils as another factor which interferes with the movement of water in the soil.

Chemical analysis of the exchangeable cations and the paste saturation extract of the studied profiles are presented in tables 2 and 3 respectively. All soil profiles studied presented alkaline character, for both $\mathrm{pH}$ values measured in water and $\mathrm{pH}$ values measured in $\mathrm{KCl}$, in the exchange complex (Table 2) and in the saturation extract (Table 3). $\mathrm{pH}$ values were generally high, ranging from 6.13 to $8.67 \mathrm{in} \mathrm{KCl}$ and from 6.80 to 10.40 in water. In the saturation extract, $\mathrm{pH}$ values ranged 7.05 to 9.43 . These $\mathrm{pH}$ in water ranges may be considered unsuitable for the development of most cultures due to strong alkalinity. Negative values of $\Delta \mathrm{pH}$ found in the soil samples characterize these soils as being predominantly electronegative.

Exchangeable calcium levels ranged from 0.39 to $37.77 \mathrm{cmol}_{\mathrm{c}} \mathrm{kg}^{-1}$, magnesium levels ranged from 0.49 to 12.17 $\mathrm{cmol}_{\mathrm{c}} \mathrm{kg}^{-1}$, sodium levels ranged from 1.87 to $14.13 \mathrm{cmol}_{\mathrm{c}} \mathrm{kg}^{-1}$, and potassium content varied from 0.06 to 0.63 $\mathrm{cmol}_{\mathrm{c}} \mathrm{kg}^{-1}$ (Table 2). It is thus observed that despite high levels of calcium and magnesium, soils also presented high levels of exchangeable sodium, which characterized them as sodic soils throughout the profile, with the exception of Apz 1 horizon, in the P1 soil profile and Ap horizon, in the P3 soil profile. The ESP values were very high in all soil profiles studied and they were very high in respect to depth as well. Freire et al. (2003) found that ESP values less than $15 \%$, which is the threshold for classifying the soil as sodic according to the classification proposed by Richards (1954), was enough to reduce the hydraulic conductivity of soils of the semiarid region of Pernambuco. Thus, besides the predominance of fine particles (Table 1) these soils must provide these dispersed particles as a function of the disruption of the soil due to the very high ESP values found in this study. 
Table 2. Chemical attributes of the soil profiles studied—exchange complex

\begin{tabular}{|c|c|c|c|c|c|c|c|c|c|c|c|}
\hline \multirow{2}{*}{ Horizon } & \multirow{2}{*}{ Depth } & \multicolumn{2}{|c|}{$\mathrm{pH}$} & \multirow{2}{*}{$\Delta \mathrm{pH}$} & \multirow{2}{*}{$\mathrm{Ca}^{2+}$} & \multirow{2}{*}{$\mathrm{Mg}^{2+}$} & \multirow{2}{*}{$\mathrm{Na}^{+}$} & \multirow{2}{*}{$\mathrm{K}^{+}$} & \multirow{2}{*}{ CEC } & \multirow{2}{*}{ ESP } & \multirow{2}{*}{$\mathrm{OC}$} \\
\hline & & $\mathrm{KCl}$ & Water & & & & & & & & \\
\hline & \multicolumn{3}{|l|}{$\mathrm{cm}$} & & \multicolumn{5}{|c|}{---1--- $\mathrm{cmol}_{\mathrm{c}} \mathrm{kg}^{-1}$} & $\%$ & $\mathrm{~g} \mathrm{~kg}^{-1}$ \\
\hline \multicolumn{12}{|c|}{ P1_Fluvisol (NEOSSOLO FLÚVICO sódico sálico) } \\
\hline Apz1 & $0-10$ & 6.85 & 7.70 & -0.85 & 37.77 & 8.82 & 5.52 & 0.63 & 52.75 & 10.46 & 12.9 \\
\hline Apz2 & $10-28$ & 6.88 & 8.10 & -1.22 & 16.36 & 6.75 & 5.71 & 0.29 & 29.11 & 19.61 & 5.8 \\
\hline $2 \mathrm{Cz} 1$ & $28-52$ & 6.51 & 8.00 & -1.49 & 22.93 & 12.17 & 7.63 & 0.29 & 43.01 & 17.73 & 7.1 \\
\hline $2 \mathrm{Cz} 2$ & $52-82$ & 6.51 & 8.20 & -1.69 & 20.30 & 9.62 & 8.77 & 0.35 & 39.04 & 22.46 & 7.7 \\
\hline 2Cgvz1 & $82-130$ & 6.40 & 8.00 & -1.60 & 19.59 & 11.23 & 9.84 & 0.35 & 41.01 & 24.00 & 7.0 \\
\hline $2 \mathrm{Cgvz} 2$ & $130-160$ & 6.40 & 8.20 & -1.80 & 21.92 & 11.29 & 10.19 & 0.23 & 43.65 & 23.37 & 7.5 \\
\hline \multicolumn{12}{|c|}{ P2-Cambisol (CAMBISSOLO FLUUVICO sódico salino) } \\
\hline Ap1 & $0-5$ & 7.90 & 8.20 & -0.30 & 11.74 & 8.53 & 5.13 & 0.18 & 25.58 & 20.07 & 6.5 \\
\hline 2Ap2 & $5-20$ & 6.97 & 8.10 & -1.13 & 10.50 & 9.89 & 5.71 & 0.18 & 26.28 & 21.72 & 4.0 \\
\hline $2 \mathrm{Bi}$ & $20-48$ & 6.44 & 8.40 & -1.96 & 13.13 & 8.82 & 5.52 & 0.16 & 27.63 & 19.97 & 4.4 \\
\hline $2 \mathrm{BC}$ & $48-85$ & 6.38 & 8.50 & -2.12 & 15.45 & 7.08 & 4.85 & 0.08 & 27.46 & 17.65 & 3.5 \\
\hline $2 \mathrm{C} 1$ & $85-120$ & 6.53 & 8.70 & -2.17 & 8.38 & 7.28 & 4.27 & 0.08 & 20.02 & 21.33 & 2.5 \\
\hline $3 \mathrm{C} 2$ & $120-190$ & 6.29 & 8.80 & -2.51 & 11.21 & 9.56 & 5.33 & 0.09 & 26.19 & 20.33 & 2.8 \\
\hline \multicolumn{12}{|c|}{ P3—Fluvisol (NEOSSOLO FLÚVICO sódico sálico) } \\
\hline Ap & $0-10$ & 6.13 & 6.80 & -0.67 & 13.84 & 7.95 & 3.22 & 0.19 & 25.20 & 12.76 & 8.8 \\
\hline $\mathrm{Cv}$ & $10-40$ & 6.88 & 8.90 & -2.02 & 9.69 & 7.82 & 11.27 & 0.14 & 28.93 & 38.96 & 3.6 \\
\hline $2 \mathrm{C}$ & $40-75$ & 6.82 & 8.80 & -1.98 & 8.18 & 7.95 & 11.99 & 0.13 & 28.25 & 42.43 & 4.3 \\
\hline $3 \mathrm{Cg} 1$ & $75-120$ & 6.94 & 9.10 & -2.16 & 4.04 & 5.15 & 8.87 & 0.11 & 18.18 & 48.83 & 1.9 \\
\hline $4 \mathrm{Cg} 2$ & $120-150$ & 7.34 & 9.50 & -2.16 & 0.39 & 0.49 & 1.87 & 0.06 & 2.81 & 66.54 & 1.4 \\
\hline \multicolumn{12}{|c|}{ P4-Cambisol (CAMBISSOLO FLUUVICO sódico salino) } \\
\hline Ap & $0-12$ & 6.25 & 7.00 & -0.75 & 8.08 & 1.27 & 1.87 & 0.41 & 11.63 & 16.11 & 15.1 \\
\hline BA & $12-26$ & 7.97 & 9.70 & -1.73 & 10.00 & 1.54 & 6.67 & 0.18 & 18.74 & 35.59 & 4.4 \\
\hline $\mathrm{Bi}$ & $26-60$ & 8.30 & 10.00 & -1.70 & 9.29 & 0.67 & 13.41 & 0.46 & 23.84 & 56.27 & 1.9 \\
\hline $\mathrm{C} 1$ & $60-100$ & 8.66 & 10.30 & -1.64 & 11.41 & 2.80 & 14.13 & 0.41 & 28.76 & 49.14 & 1.7 \\
\hline $\mathrm{C} 2$ & $100-160$ & 8.60 & 10.40 & -1.80 & 4.34 & 0.25 & 14.13 & 0.35 & 19.08 & 74.08 & 1.5 \\
\hline $2 \mathrm{C} 3$ & $160-200$ & 8.67 & 10.40 & -1.73 & 2.22 & 0.52 & 9.84 & 0.23 & 12.82 & 76.76 & 1.4 \\
\hline
\end{tabular}

Note. CEC $=$ cation exchange capacity. $\mathrm{ESP}=$ exchangeable sodium percentage. $\mathrm{OC}=$ organic carbon. 
Table 3. Chemical attributes of the soil profiles studied-saturation extract

\begin{tabular}{|c|c|c|c|c|c|c|c|c|c|c|c|}
\hline Horizon & Depth & $\mathrm{pH}$ & $\mathrm{EC}$ & $\mathrm{Ca}^{2+}$ & $\mathrm{Mg}^{2+}$ & $\mathrm{Na}^{+}$ & $\mathrm{K}^{+}$ & $\mathrm{Cl}^{-}$ & $\mathrm{CO}_{3}{ }^{2-}$ & $\mathrm{HCO}_{3}^{-}$ & $\mathrm{SO}_{4}^{-}$ \\
\hline & $\mathrm{cm}$ & & $\mathrm{dS} \mathrm{m}^{-1}$ & $\begin{array}{ll}------- \\
\end{array}$ & ------- & ---------- & $----\mathrm{mr}$ & $\mathrm{ol}_{\mathrm{c}} \mathrm{L}^{-1}$ & 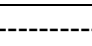 & ----- & ---------- \\
\hline \multicolumn{12}{|c|}{ P1_Fluvisol (NEOSSOLO FLÚVICO sódico sálico) } \\
\hline Apz1 & $0-10$ & 7.05 & 59.63 & 621.74 & 36.27 & 471.10 & 3.11 & 1180.0 & ND & 6.60 & 14.81 \\
\hline Apz2 & $10-28$ & 7.30 & 17.25 & 35.58 & 2.10 & 187.28 & 0.28 & 185.0 & ND & 5.80 & 12.87 \\
\hline $2 \mathrm{Cz} 1$ & $28-52$ & 7.57 & 13.35 & 08.34 & 1.60 & 153.83 & 0.24 & 113.0 & ND & 5.40 & 17.15 \\
\hline $2 \mathrm{Cz} 2$ & $52-82$ & 7.98 & 9.08 & 11.82 & 0.59 & 95.47 & 0.17 & 78.0 & ND & 8.60 & 7.51 \\
\hline 2Cgvz1 & $82-130$ & 7.52 & 8.28 & 9.24 & 0.51 & 80.02 & 0.15 & 70.0 & ND & 4.60 & 7.17 \\
\hline 2Cgvz2 & $130-160$ & 7.31 & 6.16 & 6.87 & 0.34 & 59.42 & 0.11 & 49.0 & ND & 4.20 & 5.60 \\
\hline \multicolumn{12}{|c|}{ P2-Cambisol (CAMBISSOLO FLUUVICO sódico salino) } \\
\hline Ap1 & $0-5$ & 7.10 & 65.97 & 21.65 & 92.52 & 471.10 & 4.79 & 2520.0 & ND & 25.40 & 150.62 \\
\hline 2Ap2 & $5-20$ & 7.77 & 20.11 & 44.51 & 4.68 & 248.99 & 0.34 & 183.0 & ND & 11.00 & 42.04 \\
\hline 2Ap2 & $5-20$ & 7.77 & 20.11 & 44.51 & 4.68 & 248.99 & 0.34 & 183.0 & ND & 11.00 & 42.04 \\
\hline $2 \mathrm{Bi}$ & $20-48$ & 7.68 & 7.44 & 18.84 & 1.52 & 74.87 & 0.09 & 30.0 & ND & 6.60 & 19.98 \\
\hline $2 \mathrm{BC}$ & $48-85$ & 7.37 & 5.83 & 11.51 & 0.76 & 57.71 & 0.08 & 26.0 & ND & 4.60 & 12.37 \\
\hline $2 \mathrm{C} 1$ & $85-120$ & 7.47 & 4.89 & 6.67 & 0.51 & 43.98 & 0.07 & 28.0 & ND & 6.20 & 8.99 \\
\hline $3 \mathrm{C} 2$ & $120-190$ & 7.68 & 3.92 & 6.46 & 0.42 & 38.83 & 0.06 & 22.0 & ND & 6.60 & 7.54 \\
\hline \multicolumn{12}{|c|}{ P3-Fluvisol (NEOSSOLO FLUUVICO sódico sálico) } \\
\hline Ap & $0-10$ & 7.56 & 39.87 & 424.12 & 25.17 & 414.46 & 1.74 & 640.0 & ND & 9.00 & 156.14 \\
\hline $\mathrm{Cv}$ & $10-40$ & 8.03 & 12.59 & 4.90 & 0.76 & 146.97 & 0.08 & 127.0 & ND & 9.80 & 5.38 \\
\hline $2 \mathrm{C}$ & $40-75$ & 8.06 & 12.38 & 2.67 & 0.76 & 129.80 & 0.06 & 125.0 & ND & 9.40 & 4.49 \\
\hline $3 \mathrm{Cg} 1$ & $75-120$ & 7.95 & 10.88 & 2.83 & 0.51 & 119.50 & 0.06 & 106.0 & ND & 8.60 & 2.83 \\
\hline $4 \mathrm{Cg} 2$ & $120-150$ & 7.67 & 8.80 & 2.19 & 0.25 & 93.76 & 0.07 & 80.0 & ND & 5.80 & 2.11 \\
\hline \multicolumn{12}{|c|}{ P4-Cambisol (CAMBISSOLO FLUUVICO sódico salino) } \\
\hline Ap & $0-12$ & 8.32 & 8.60 & 12.12 & 0.67 & 93.76 & 0.91 & 82.0 & ND & 19.40 & 1.50 \\
\hline BA & $12-26$ & 8.35 & 12.72 & 7.02 & 0.17 & 150.40 & 0.13 & 124.0 & ND & 25.40 & 7.17 \\
\hline $\mathrm{Bi}$ & $26-60$ & 8.43 & 21.42 & 6.67 & 0.06 & 317.57 & 0.49 & 263.0 & ND & 21.00 & 10.64 \\
\hline $\mathrm{C} 1$ & $60-100$ & 9.20 & 19.53 & 4.44 & 0.04 & 276.42 & 0.39 & 212.0 & 3.00 & 26.20 & 7.96 \\
\hline $\mathrm{C} 2$ & $100-160$ & 9.43 & 16.32 & 10.81 & 0.05 & 207.85 & 0.18 & 157.0 & 2.80 & 27.40 & 5.44 \\
\hline $2 \mathrm{C} 3$ & $160-200$ & 9.29 & 13.39 & 5.00 & 0.04 & 155.55 & 0.24 & 127.0 & 2.33 & 34.33 & 4.25 \\
\hline
\end{tabular}

Note. $\mathrm{EC}=$ electrical conductivity. $\mathrm{ND}=$ not detected.

Oliveira et al. (2003) consider values less than $10 \mathrm{~g} \mathrm{~kg}^{-1}$ as low organic carbon content, which is compatible with land use and the prevailing weather conditions in the semiarid region. In the soil profiles studied these values were low and ranged from 1.4 to $15.1 \mathrm{~g} \mathrm{~kg}^{-1}$ (Table 2) According to Wong et al. (2010), in these areas, carbon levels and fluctuations are directly related to decreased plant inputs due to low biomass production and hence, low soil organic matter (SOM) accumulation which will, subsequently, affect soil carbon and nutrient cycling.

In saturation extract the values of EC were high in all soil profiles and depths (Table 3). In profiles 1, 2 and 3, EC values were reduced in respect to depth, indicating a higher concentration of salts on the surface. Salts were evenly distributed throughout the profile only in the case of P4. Pessoa et al. (2012) found that the growth of onions in the irrigated soils of Cachoeira II, located in Serra Talhada in the semiarid region from the state of Pernambuco, was affected at a soil salinity of $2.56 \mathrm{dS} \mathrm{m}^{-1}$. Thus, the EC values found in this study indicate that the cultivation of glycophyte plants is impossible in these areas, since the salinity of the surface horizons was quite high, which requires recovery strategies and the cultivation of halophytic plants.

The content of soluble cations $\left(\mathrm{Ca}^{2+}, \mathrm{Mg}^{2+}, \mathrm{Na}^{+}\right.$and $\left.\mathrm{K}^{+}\right)$and anions $\left(\mathrm{Cl}^{-}, \mathrm{CO}_{3}{ }^{2-}, \mathrm{HCO}_{3}{ }^{-}\right.$and $\left.\mathrm{SO}_{4}{ }^{2-}\right)$ were extremely high in surface profiles with large decreases in respect to depth in profiles 1, 2 and 3 (Table 3 ). This reduction of the levels of soluble cations and anions in these profiles, confirm the values obtained for EC, which were also reduced over the soil profile. P4 had well distributed levels of soluble cations and anions along the profile, also corroborating the EC values recorded in this profile. 
With the exception of the upper horizons in P1 and P3, it is observed that in all other subsurface horizons of the studied profiles, the soluble $\mathrm{Na}^{+}$presents higher levels than the other cations, ranging from 38.83 to 471.10 $\mathrm{mmol}_{\mathrm{c}} \mathrm{L}^{-1}$ (Table 3). This reflects the predominance of soluble $\mathrm{Na}^{+}$in relation to $\mathrm{Ca}^{2+}$ and $\mathrm{Mg}^{2+}$. Similarly to exchange complex, the $\mathrm{K}^{+}$cation was detected at lower levels than other cations.

With respect to anions, $\mathrm{Cl}^{-}$was found in higher concentrations, mainly in the superficial horizons of the profiles, except in P4 (Table 3). At high concentrations this element is toxic to most crops and remediation practices require the removal of this element. The high levels of this element along with the observed high levels of $\mathrm{Na}^{+}$ indicate the predominance of $\mathrm{NaCl}$ salts.

Concentrations of $\mathrm{CO}_{3}{ }^{2-}$ were absent in profiles 1,2 and 3 (Table 3). This element was detected only in the lower horizons of profile $\mathrm{P} 4$, but at much lower levels as compared to other anions. These low levels observed in these profiles are likely to have been derived from source material. However, the data in this study indicate that $\mathrm{CO}_{3}{ }^{2-}$ has no restriction on soils. These data suggest that high $\mathrm{pH}$ values observed are more strongly associated with $\mathrm{HCO}_{3}{ }^{-}$, which was found in considerable amounts in all profiles analyzed. In soil profile P4, where the levels of $\mathrm{HCO}_{3}{ }^{-}$were highest, we observed high $\mathrm{pH}$ values both in saturation extract (Table 3 ), as well as in the exchange complex (Table 2). It was only in the case of $\mathrm{P} 3$ that $\mathrm{HCO}_{3}{ }^{-}$levels were higher than $\mathrm{SO}_{4}{ }_{4}^{2-}$.

To understand how these ions are associated in the soil solution, the ionic speciation of the soil solution was performed, which indicated that the soluble cations $\mathrm{Ca}^{2+}, \mathrm{Mg}^{2+}, \mathrm{Na}^{+}$and $\mathrm{K}^{+}$predominate in their free ionic forms, but are more strongly associated with the anions $\mathrm{Cl}^{-}$and $\mathrm{SO}_{4}{ }^{2-}$ in all horizons of the soil profiles evaluated (Tables 4 to 7). With regard to anions, the data indicates that free $\mathrm{CO}_{3}{ }^{2-}$ occurs to a lesser extent compared to the other anions, which is due to the low levels recorded in the analysis of the in the saturation extract (Table 3). The anions $\mathrm{HCO}_{3}^{-}, \mathrm{Cl}^{-}$and $\mathrm{SO}_{4}{ }^{2-}$ presented similar behavior to cations, predominating in free forms, but with their most significant associations occurring with the cations $\mathrm{Ca}^{2+}, \mathrm{Mg}^{2+}$ and $\mathrm{Na}^{+}$.

The ionic speciation indicated the predominance of free forms of $\mathrm{Ca}^{2+}, \mathrm{Mg}^{2+}, \mathrm{Na}^{+}$and $\mathrm{K}^{+}, \mathrm{HCO}_{3}{ }^{-}, \mathrm{Cl}^{-}$and $\mathrm{SO}_{4}{ }^{2-}$ as well chloride and sulfate salt associations with calcium, magnesium and sodium in halomorphic soils in the semiarid region of Pernambuco State (Tables 4 to 7). This provides important information on the toxicity of these ions, which in their free forms are more toxic. Several studies have demonstrated the influence of free ions and associates in saline conditions on mineral nutrition and reduced plant growth (Miranda et al., 2002; Lacerda et al., 2004; Farias et al, 2009; Carmona et al., 2010).

With the exception of $\mathrm{P} 4$, it was found that the ions (cations and anions) in their free forms, occur more significantly in the subsurface and the deeper horizons. As can be seen in Table 3, element contents are reduced in respect to depth. This favors a reduction in the ionic strength of the soil solution, which contributes to the higher incidence of these ions in their free forms. The ionic strength related to the total electrolyte concentration influences the activity of ions in solution (Lindsay, 1979). Profile 4 showed an inverse behavior as compared to other profiles, showing an increase in the levels of soluble elements in respect to depth (Table 3), favoring a higher percentage of associations in respect to depth in this soil profile.

Thus, forms associated with chloride $\left(\mathrm{CaCl}^{+}, \mathrm{MgCl}^{+}, \mathrm{NaCl}\right.$ and $\left.\mathrm{KCl}\right)$, sulfate $\left(\mathrm{CaSO}_{4}, \mathrm{MgSO}_{4}, \mathrm{NaSO}_{4}^{-}\right.$and $\left.\mathrm{K}_{2} \mathrm{SO}_{4}{ }^{-}\right)$and bicarbonates $\left(\mathrm{CaHCO}_{3}{ }^{+}, \mathrm{MgHCO}_{3}{ }^{+}\right.$and $\left.\mathrm{NaHCO}_{3}\right)$ are more significant in the surface horizons and it is possible observe a reduction of this association in the deeper horizons. This shows that in the deeper horizons of soil profiles ions change from associated forms to free forms. In addition, sodium is the element that is in its free ionic form appears at a highest percentage than the other evaluated cations. This information is crucial since the free sodium in the soil solution can move to the exchangeable form, damaging the soil structure. 
Table 4. Geochemical speciation of soluble salts in the P1—Fluvisol (NEOSSOLO FLÚVICO sódico sálico)

\begin{tabular}{|c|c|c|c|c|c|c|c|}
\hline \multirow{2}{*}{ Ion } & \multirow{2}{*}{ Specie name } & \multicolumn{6}{|c|}{$\%$ of total concentration in each soil horizon } \\
\hline & & Apz1 & Apz2 & $2 \mathrm{Cz} 1$ & $2 \mathrm{Cz} 2$ & 2Cgvz1 & 2Cgvz2 \\
\hline \multicolumn{8}{|l|}{ Cations in Saturation Extract } \\
\hline \multirow[t]{3}{*}{ Calcium } & $\mathrm{Ca}^{2+}$ & 47.80 & 79.16 & 73.33 & 82.46 & 81.83 & 83.12 \\
\hline & $\mathrm{CaCl}^{+}$ & 50.16 & 10.21 & 6.43 & 5.56 & 5.20 & 4.06 \\
\hline & $\mathrm{CaSO}_{4}$ & 2.04 & 10.63 & 20.24 & 11.98 & 12.98 & 12.82 \\
\hline \multirow[t]{3}{*}{ Magnesium } & $\mathrm{Mg}^{2+-}$ & 37.08 & 76.27 & 73.62 & 81.80 & 81.52 & 83.34 \\
\hline & $\mathrm{MgCl}^{+}$ & 61.67 & 15.59 & 10.23 & 8.76 & 8.20 & 6.45 \\
\hline & $\mathrm{MgSO}_{4}$ & 1.26 & 8.14 & 16.15 & 9.44 & 10.27 & 10.21 \\
\hline \multirow[t]{3}{*}{ Sodium } & $\mathrm{Na}^{+-\cdots}$ & 82.69 & 94.69 & 95.16 & 96.90 & 97.02 & 97.63 \\
\hline & $\mathrm{NaCl}$ & 17.09 & 4.22 & 2.82 & 2.13 & 1.97 & 1.47 \\
\hline & $\mathrm{NaSO}_{4}^{-}$ & 0.21 & 1.09 & 2.03 & 0.97 & 1.01 & 0.90 \\
\hline \multirow[t]{3}{*}{ Potassium } & $\mathrm{K}^{+-}$ & 82.64 & 94.39 & 94.60 & 96.63 & 96.73 & 97.38 \\
\hline & $\mathrm{KCl}$ & 17.08 & 4.21 & 2.80 & 2.12 & 1.96 & 1.46 \\
\hline & $\mathrm{KSO}_{4}^{-}$ & 0.27 & 1.40 & 2.60 & 1.25 & 1.30 & 1.16 \\
\hline \multicolumn{8}{|l|}{ Anions in Saturation Extract } \\
\hline \multirow[t]{9}{*}{ Carbonate and Bicarbonate } & $\mathrm{CO}_{3}{ }^{2-}$ & 0.02 & 0.19 & 0.36 & 0.86 & 0.29 & 0.17 \\
\hline & $\mathrm{MgCO}_{3}$ & 0.06 & 0.02 & 0.04 & 0.04 & 0.01 & - \\
\hline & $\mathrm{CaCO}_{3}$ & 2.56 & 0.71 & 0.35 & 1.73 & 0.49 & 0.25 \\
\hline & $\mathrm{NaCO}_{3}^{-}$ & 0.10 & 0.18 & 0.32 & 0.53 & 0.16 & 0.07 \\
\hline & $\mathrm{H}_{2} \mathrm{CO}_{3}$ & 3.62 & 6.30 & 3.91 & 1.57 & 4.62 & 7.58 \\
\hline & $\mathrm{HCO}_{3}^{-}$ & 28.82 & 80.19 & 88.96 & 88.79 & 89.05 & 87.64 \\
\hline & $\mathrm{NaHCO}_{3}$ & 3.03 & 3.66 & 3.57 & 2.39 & 2.07 & 1.60 \\
\hline & $\mathrm{MgHCO}_{3}^{+}$ & 2.16 & 0.37 & 0.35 & 0.16 & 0.14 & 0.10 \\
\hline & $\mathrm{CaHCO}_{3}^{+}$ & 59.62 & 8.39 & 2.15 & 3.93 & 3.18 & 2.59 \\
\hline \multirow[t]{5}{*}{ Sulfate } & $\mathrm{SO}_{4}^{2-}$ & 5.70 & 54.39 & 70.56 & 68.06 & 71.28 & 74.04 \\
\hline & $\mathrm{MgSO}_{4}$ & 3.02 & 1.25 & 1.52 & 0.74 & 0.73 & 0.62 \\
\hline & $\mathrm{CaSO}_{4}$ & 84.56 & 28.63 & 9.53 & 18.82 & 16.65 & 15.73 \\
\hline & $\mathrm{NaSO}_{4}^{-}$ & 6.67 & 15.69 & 18.36 & 12.34 & 11.32 & 9.59 \\
\hline & $\mathrm{KSO}_{4}^{-}$ & 0.06 & 0.03 & 0.03 & 0.03 & 0.03 & 0.02 \\
\hline \multirow[t]{5}{*}{ Chloride } & $\mathrm{Cl}^{--}$ & 64.81 & 93.62 & 95.56 & 96.49 & 97.00 & 97.60 \\
\hline & $\mathrm{CaCl}^{+}$ & 26.44 & 1.93 & 0.46 & 0.84 & 0.68 & 0.57 \\
\hline & $\mathrm{MgCl}^{+}$ & 1.88 & 0.17 & 0.15 & 0.07 & 0.06 & 0.05 \\
\hline & $\mathrm{KCl}$ & 0.04 & - & - & - & - & - \\
\hline & $\mathrm{NaCl}$ & 6.82 & 4.27 & 3.84 & 2.60 & 2.25 & 1.78 \\
\hline
\end{tabular}


Table 5. Geochemical speciation of soluble salts in the P2-Cambisol (CAMBISSOLO FLÚVICO sódico salino)

\begin{tabular}{|c|c|c|c|c|c|c|c|}
\hline \multirow{2}{*}{ Ion } & \multirow{2}{*}{ Specie name } & \multicolumn{6}{|c|}{$\%$ of total concentration in each soil horizon } \\
\hline & & Ap1 & $2 \mathrm{Ap} 2$ & $2 \mathrm{Bi}$ & $2 \mathrm{BC}$ & $2 \mathrm{C} 1$ & $3 \mathrm{C} 2$ \\
\hline \multicolumn{8}{|l|}{ Cations in Saturation Extract } \\
\hline \multirow[t]{3}{*}{ Calcium } & $\mathrm{Ca}^{2+}$ & 12.26 & 66.43 & 71.20 & 74.97 & 76.12 & 78.03 \\
\hline & $\mathrm{CaCl}^{+}$ & 43.01 & 8.11 & 1.89 & 1.91 & 2.26 & 1.90 \\
\hline & $\mathrm{CaSO}_{4}$ & 44.73 & 25.47 & 26.91 & 23.12 & 21.62 & 20.07 \\
\hline \multirow[t]{3}{*}{ Magnesium } & $\mathrm{Mg}^{2+-}$ & 10.57 & 66.76 & 74.49 & 77.79 & 78.57 & 80.45 \\
\hline & $\mathrm{MgCl}^{+}$ & 58.79 & 12.91 & 3.13 & 3.15 & 3.70 & 3.10 \\
\hline & $\mathrm{MgSO}_{4}$ & 30.64 & 20.33 & 22.38 & 19.06 & 17.73 & 16.44 \\
\hline \multirow[t]{3}{*}{ Sodium } & $\mathrm{Na}^{+-}$ & 54.36 & 92.88 & 96.71 & 97.40 & 97.57 & 97.94 \\
\hline & $\mathrm{NaCl}$ & 34.67 & 3.92 & 0.83 & 0.77 & 0.87 & 0.70 \\
\hline & $\mathrm{NaSO}_{4}^{-}$ & 10.97 & 3.20 & 2.46 & 1.83 & 1.56 & 1.36 \\
\hline \multirow[t]{3}{*}{ Potassium } & $\mathrm{K}^{+-}$ & 52.69 & 92.03 & 96.03 & 96.89 & 97.13 & 97.55 \\
\hline & $\mathrm{KCl}$ & 33.61 & 3.89 & 0.82 & 0.77 & 0.87 & 0.70 \\
\hline & $\mathrm{KSO}_{4}^{-}$ & 13.70 & 4.08 & 3.15 & 2.34 & 2.01 & 1.75 \\
\hline \multicolumn{8}{|l|}{ Anions in Saturation Extract } \\
\hline \multirow[t]{9}{*}{ Carbonate and Bicarbonate } & $\mathrm{CO}_{3}^{2-}$ & 0.07 & 0.57 & 0.24 & 0.19 & 0.23 & 0.37 \\
\hline & $\mathrm{MgCO}_{3}$ & 0.15 & 0.11 & 0.03 & 0.02 & 0.01 & 0.02 \\
\hline & $\mathrm{CaCO}_{3}$ & 0.08 & 2.13 & 0.68 & 0.43 & 0.36 & 0.62 \\
\hline & $\mathrm{NaCO}_{3}^{-}$ & 0.20 & 0.70 & 0.12 & 0.08 & 0.08 & 0.12 \\
\hline & $\mathrm{H}_{2} \mathrm{CO}_{3}$ & 8.83 & 2.09 & 5.33 & 6.54 & 5.48 & 3.48 \\
\hline & $\mathrm{HCO}_{3}^{-}$ & 78.64 & 80.33 & 86.04 & 87.16 & 89.92 & 91.46 \\
\hline & $\mathrm{NaHCO}_{3}$ & 5.61 & 4.64 & 1.84 & 1.53 & 1.25 & 1.15 \\
\hline & $\mathrm{MgHCO}_{3}{ }^{+}$ & 4.81 & 0.74 & 0.37 & 0.21 & 0.16 & 0.14 \\
\hline & $\mathrm{CaHCO}_{3}^{+}$ & 1.62 & 8.69 & 5.36 & 3.84 & 2.51 & 2.63 \\
\hline \multirow[t]{5}{*}{ Sulfate } & $\mathrm{SO}_{4}^{2-\cdots}$ & 40.00 & 51.82 & 63.55 & 68.78 & 75.29 & 74.86 \\
\hline & $\mathrm{MgSO}_{4}$ & 18.82 & 2.26 & 1.70 & 1.17 & 1.01 & 0.92 \\
\hline & $\mathrm{CaSO}_{4}$ & 6.43 & 26.96 & 25.38 & 21.51 & 16.04 & 17.19 \\
\hline & $\mathrm{NaSO}_{4}^{-}$ & 34.31 & 18.93 & 9.23 & 8.53 & 7.65 & 7.02 \\
\hline & $\mathrm{KSO}_{4}^{-}$ & 0.44 & 0.03 & 0.14 & 0.02 & 0.02 & 0.01 \\
\hline \multirow[t]{5}{*}{ Chloride } & $\mathrm{Cl}^{-}$ & 90.93 & 92.36 & 96.56 & 97.35 & 98.03 & 98.14 \\
\hline & $\mathrm{CaCl}^{+}$ & 0.37 & 1.97 & 1.19 & 0.85 & 0.54 & 0.56 \\
\hline & $\mathrm{MgCl}^{+}$ & 2.16 & 0.33 & 0.16 & 0.09 & 0.07 & 0.06 \\
\hline & $\mathrm{KCl}$ & 0.06 & - & 0.02 & - & - & - \\
\hline & $\mathrm{NaCl}$ & 6.48 & 5.34 & 2.07 & 1.71 & 1.37 & 1.24 \\
\hline
\end{tabular}


Table 6. Geochemical speciation of soluble salts in the P3-Fluvisol (NEOSSOLO FLÚVICO sódico sálico)

\begin{tabular}{|c|c|c|c|c|c|c|}
\hline \multirow{2}{*}{ Ion } & \multirow{2}{*}{ Specie name } & \multicolumn{5}{|c|}{$\%$ of total concentration in each soil horizon } \\
\hline & & Ap & $\mathrm{Cv}$ & $2 \mathrm{C}$ & $3 \mathrm{Cg} 1$ & $4 \mathrm{Cg} 2$ \\
\hline \multicolumn{7}{|l|}{ Cations in Saturation Extract } \\
\hline \multirow[t]{3}{*}{ Calcium } & $\mathrm{Ca}^{2+}$ & 49.62 & 83.49 & 77.87 & 86.86 & 88.61 \\
\hline & $\mathrm{CaCl}^{+}$ & 23.24 & 8.49 & 7.93 & 7.89 & 6.58 \\
\hline & $\mathrm{CaSO}_{4}$ & 27.14 & 8.02 & 14.20 & 5.26 & 4.82 \\
\hline \multirow[t]{3}{*}{ Magnesium } & $\mathrm{Mg}^{2+-}$ & 45.94 & 80.82 & 76.56 & 83.90 & 86.14 \\
\hline & $\mathrm{MgCl}^{+}$ & 34.10 & 13.02 & 12.35 & 12.07 & 10.13 \\
\hline & $\mathrm{MgSO}_{4}$ & 19.96 & 6.17 & 11.09 & 4.03 & 3.72 \\
\hline \multirow[t]{3}{*}{ Sodium } & $\mathrm{Na}^{+-}$ & 85.90 & 96.05 & 95.48 & 96.72 & 97.37 \\
\hline & $\mathrm{NaCl}$ & 10.40 & 3.26 & 3.24 & 2.87 & 2.29 \\
\hline & $\mathrm{NaSO}_{4}^{-}$ & 3.70 & 0.69 & 1.28 & 0.41 & 0.34 \\
\hline \multirow[t]{3}{*}{ Potassium } & $\mathrm{K}^{+}$ & 84.99 & 95.86 & 95.13 & 96.61 & 97.27 \\
\hline & $\mathrm{KCl}$ & 10.29 & 3.26 & 3.22 & 2.87 & 2.29 \\
\hline & $\mathrm{KSO}_{4}^{-}$ & 4.72 & 0.89 & 1.65 & 0.53 & 0.44 \\
\hline \multicolumn{7}{|l|}{ Anions in Saturation Extract } \\
\hline \multirow[t]{9}{*}{ Carbonate and Bicarbonate } & $\mathrm{CO}_{3}{ }^{2-}$ & 0.15 & 1.04 & 1.12 & 0.84 & 0.42 \\
\hline & $\mathrm{MgCO}_{3}$ & 0.18 & 0.06 & 0.06 & 0.04 & 0.01 \\
\hline & $\mathrm{CaCO}_{3}$ & 6.05 & 0.75 & 0.42 & 0.42 & 0.19 \\
\hline & $\mathrm{NaCO}_{3}^{-}$ & 0.38 & 0.91 & 0.87 & 0.64 & 0.27 \\
\hline & $\mathrm{H}_{2} \mathrm{CO}_{3}$ & 1.66 & 1.39 & 1.33 & 1.74 & 3.41 \\
\hline & $\mathrm{HCO}_{3}^{-}$ & 42.53 & 90.52 & 91.99 & 92.08 & 92.21 \\
\hline & $\mathrm{NaHCO}_{3}$ & 3.75 & 3.57 & 3.21 & 3.09 & 2.55 \\
\hline & $\mathrm{MgHCO}_{3}^{+}$ & 1.92 & 0.19 & 0.19 & 0.14 & 0.08 \\
\hline & $\mathrm{CaHCO}_{3}^{+}$ & 43.40 & 1.57 & 0.82 & 1.02 & 0.87 \\
\hline \multirow[t]{5}{*}{ Sulfate } & $\mathrm{SO}_{4}^{2---}$ & 13.18 & 72.98 & 77.34 & 76.77 & 79.39 \\
\hline & $\mathrm{MgSO}_{4}$ & 3.22 & 0.87 & 0.90 & 0.73 & 0.44 \\
\hline & $\mathrm{CaSO}_{4}$ & 73.72 & 7.31 & 4.03 & 5.26 & 5.00 \\
\hline & $\mathrm{NaSO}_{4}^{-}$ & 9.82 & 18.83 & 17.72 & 17.24 & 15.15 \\
\hline & $\mathrm{KSO}_{4}^{-}$ & 0.05 & 0.01 & 0.01 & 0.01 & 0.02 \\
\hline \multirow[t]{5}{*}{ Chloride } & $\mathrm{Cl}^{-}$ & 76.50 & 95.82 & 96.39 & 96.50 & 97.10 \\
\hline & $\mathrm{CaCl}^{+}$ & 15.40 & 0.33 & 0.17 & 0.21 & 0.18 \\
\hline & $\mathrm{MgCl}^{+}$ & 1.34 & 0.08 & 0.08 & 0.06 & 0.03 \\
\hline & $\mathrm{KCl}$ & 0.03 & 3.78 & - & - & - \\
\hline & $\mathrm{NaCl}$ & 6.74 & 95.82 & 3.36 & 3.23 & 2.68 \\
\hline
\end{tabular}


Table 7. Geochemical speciation of soluble salts in the P4-Cambisol (CAMBISSOLO FLÚVICO sódico salino)

\begin{tabular}{|c|c|c|c|c|c|c|c|}
\hline \multirow{2}{*}{ Ion } & \multirow{2}{*}{ Specie name } & \multicolumn{6}{|c|}{$\%$ of total concentration in each soil horizon } \\
\hline & & Ap & BA & $\mathrm{Bi}$ & $\mathrm{C} 1$ & $\mathrm{C} 2$ & $2 \mathrm{C} 3$ \\
\hline \multicolumn{8}{|l|}{ Cations in Saturation Extract } \\
\hline \multirow[t]{5}{*}{ Calcium } & $\mathrm{Ca}^{2+}$ & 90.89 & 81.89 & 76.98 & 76.72 & 79.60 & 80.92 \\
\hline & $\mathrm{CaCl}^{+}$ & 6.50 & 8.05 & 13.64 & 11.32 & 9.17 & 8.18 \\
\hline & $\mathrm{CaSO}_{4}$ & 2.61 & 10.06 & 9.38 & 7.79 & 5.98 & 6.09 \\
\hline & $\mathrm{CaHCO}_{3}^{+}$ & - & - & - & 0.54 & 0.43 & 0.49 \\
\hline & $\mathrm{CaCO}_{3}$ & - & - & - & 3.62 & 4.82 & 4.32 \\
\hline \multirow[t]{6}{*}{ Magnesium } & $\mathrm{Mg}^{2+}$ & 87.98 & 79.80 & 72.60 & 74.27 & 78.06 & 79.70 \\
\hline & $\mathrm{MgCl}^{+}$ & 9.98 & 12.41 & 20.38 & 17.38 & 14.26 & 12.77 \\
\hline & $\mathrm{MgSO}_{4}$ & 2.04 & 7.79 & 7.02 & 5.99 & 4.66 & 4.76 \\
\hline & $\mathrm{MgOH}^{+}$ & - & - & - & 0.18 & 0.33 & 0.26 \\
\hline & $\mathrm{MgCO}_{3}$ & - & - & - & 1.76 & 2.37 & 2.13 \\
\hline & $\mathrm{MgHCO}_{3}{ }^{+}$ & - & - & - & 0.42 & 0.33 & 0.39 \\
\hline \multirow[t]{5}{*}{ Sodium } & $\mathrm{Na}^{+}$ & 97.55 & 95.95 & 93.26 & 94.15 & 95.40 & 95.99 \\
\hline & $\mathrm{NaCl}$ & 2.26 & 3.16 & 5.73 & 4.81 & 3.76 & 3.25 \\
\hline & $\mathrm{NaSO}_{4}^{-}$ & 0.19 & 0.89 & 1.01 & 0.81 & 0.58 & 0.54 \\
\hline & $\mathrm{NaHCO}_{3}$ & - & - & - & 0.05 & 0.03 & 0.04 \\
\hline & $\mathrm{NaCO}_{3}^{-}$ & - & - & - & 0.18 & 0.22 & 0.18 \\
\hline \multirow[t]{3}{*}{ Potassium } & $\mathrm{K}^{+^{--}}$ & 97.49 & 95.70 & 92.99 & 94.14 & 95.48 & 96.05 \\
\hline & $\mathrm{KCl}$ & 2.26 & 3.15 & 5.71 & 4.81 & 3.77 & 3.25 \\
\hline & $\mathrm{KSO}_{4}^{-}$ & 0.25 & 1.14 & 1.30 & 1.05 & 0.75 & 0.70 \\
\hline \multicolumn{8}{|l|}{ Anions in Saturation Extract } \\
\hline \multirow[t]{9}{*}{ Carbonate and Bicarbonate } & $\mathrm{CO}_{3}{ }^{2-}$ & 1.80 & 2.51 & 2.66 & 11.42 & 14.22 & 13.00 \\
\hline & $\mathrm{MgCO}_{3}$ & 0.11 & 0.03 & - & 0.02 & 0.04 & 0.04 \\
\hline & $\mathrm{CaCO}_{3}$ & 4.16 & 2.51 & 1.77 & 5.36 & 18.60 & 9.24 \\
\hline & $\mathrm{NaCO}_{3}^{-}$ & 1.10 & 2.23 & 4.24 & 16.41 & 16.26 & 11.97 \\
\hline & $\mathrm{H}_{2} \mathrm{CO}_{3}$ & 0.69 & 0.53 & 0.48 & 0.06 & 0.03 & 0.05 \\
\hline & $\mathrm{HCO}_{3}^{-}$ & 85.34 & 86.59 & 83.07 & 61.78 & 46.79 & 62.06 \\
\hline & $\mathrm{NaHCO}_{3}$ & 2.29 & 3.47 & 6.20 & 4.14 & 2.47 & 2.58 \\
\hline & $\mathrm{MgHCO}_{3}^{+}$ & 0.19 & 0.04 & 0.01 & - & - & - \\
\hline & $\mathrm{CaHCO}_{3}^{+}$ & 4.32 & 2.09 & 1.57 & 0.80 & 1.59 & 1.06 \\
\hline \multirow[t]{5}{*}{ Sulfate } & $\mathrm{SO}_{4}^{2-\cdots}$ & 65.93 & 71.30 & 63.92 & 67.11 & 65.84 & 72.94 \\
\hline & $\mathrm{MgSO}_{4}$ & 0.90 & 0.19 & 0.04 & 0.03 & 0.04 & 0.05 \\
\hline & $\mathrm{CaSO}_{4}$ & 21.08 & 9.85 & 5.88 & 4.35 & 11.88 & 7.16 \\
\hline & $\mathrm{NaSO}_{4}^{-}$ & 11.95 & 18.64 & 30.10 & 28.46 & 22.22 & 19.82 \\
\hline & $\mathrm{KSO}_{4}^{-}$ & 0.15 & 0.02 & 0.06 & 0.05 & 0.03 & 0.04 \\
\hline \multirow[t]{5}{*}{ Chloride } & $\mathrm{Cl}^{-}$ & 96.35 & 95.69 & 92.72 & 93.48 & 94.38 & 95.69 \\
\hline & $\mathrm{CaCl}^{+}$ & 0.96 & 0.46 & 0.35 & 0.24 & 0.63 & 0.32 \\
\hline & $\mathrm{MgCl}^{+}$ & 0.08 & 0.02 & - & - & - & - \\
\hline & $\mathrm{KCl}$ & 0.03 & - & 0.01 & - & - & - \\
\hline & $\mathrm{NaCl}$ & 2.59 & 3.84 & 6.92 & 6.28 & 4.98 & 3.98 \\
\hline
\end{tabular}

\section{Conclusion}

The profiles in the study present high levels of salts and sodium at the upper soil horizons. Furthermore, the predominance of fine particles is a factor which tends to hinder the management and recovery of these soils.

The soils selected in critical spots are classified as Fluvisols and Cambisols. Thus, these soils may be strongly associated with the presence of high levels of soil degradation by salinization and sodification in the semiarid region of Pernambuco.

The predominance of chloride and sulfate of calcium, magnesium, sodium and potassium salt in the studied soil profiles is a strong contributor to salinity in these areas. 


\section{References}

Aldabaa, A. A. A., Weindorf, D. C., Chakraborty, S., Sharma, A., \& Li, B. (2015). Combination of proximal and remote sensing methods for rapid soil salinity quantification. Geoderma, 239-240, 34-46. https://doi.org/ 10.1016/j.geoderma.2014.09.011

Arora, S. (2017). Diagnostic Properties and Constraints of Salt-Affected Soils. In S., Arora, A. K. Singh, \& Y. P. Singh (Eds.), Bioremediation of Salt Affected Soils: An Indian Perspective (pp. 41-52). Lucknow, UP: Springer International Publishing. https://doi.org/10.1007/978-3-319-48257-6_2

Carmona, F. C., Anghinoni, I., Holzschuh, M. J., \& Andrighetti, M. H. (2010). Cation dynamics in soils with different salinity levels growing irrigated rice. Revista Brasileira de Ciência do Solo, 34, 1851-1863. https://doi.org/10.1590/S0100-06832010000600009

de Albuquerque, U. P. E. D., Araujo, A. C. A., El-Deir, A. L. A., de Lima, A., Souto, B. M., Bezerra, E. M. N., ... Severi, W. (2012). Caatinga Revisited: Ecology and Conservation of an Important Seasonal Dry Forest. Scientific World Journal, 1, 1-18. https://doi.org/10.1100/2012/205182

de Andrade, J. J., Oliveira, F. J. M., Pessoa, L. G. M., Nascimento, S. A. S., Souza, E. S., Barros Júnior, G., ... Freire, M. B. G. S. (2018). Effects of elemental sulfur associated with gypsum on soil salinity attenuation and sweet sorghum growth under saline water irrigation. Australian Journal of Crop Science, 12(2), 221-226. https://doi.org/10.21475/ajcs.18.12.02.pne664

Embrapa (Empresa Brasileira de Pesquisa Agropecuária). (1997). Manual de métodos de análises de solo (2nd ed.). Rio de Janeiro, RJ: Embrapa.

Embrapa (Empresa Brasileira de Pesquisa Agropecuária). (2013). Sistema brasileiro de classificação de solos (3rd ed.). Rio de Janeiro, RJ: Embrapa.

Farias, S. G. G., dos Santos, D. R., Freire, A. L. O., \& Silva, R. B. (2009). Estresse salino no crescimento inicial e nutrição mineral de gliricídia (Gliricidia sepium (Jacq.) Kunth ex Steud) em solução nutritiva. Revista Brasileira de Ciência do Solo, 33, 1499-1505. https://doi.org/10.1590/S0100-06832009000500040

Ferreira, J., Pardini, R., Metzger, J. P., Fonseca, C. R., Pompeu, P. S., Sparovek, G., \& Louzada, J. (2012) Towards environmentally sustainable agriculture in Brazil: challenges and opportunities for applied ecological research. Journal of Applied Ecology, 49, 535-541. https://doi.org/10.1111/j.1365-2664. 2012.02145.x

Freire, M. B. G. S., Ruiz, H. Á., Ribeiro, M. R., Ferreira, P. A., Alvarez, V. H., \& Freire, F. J. (2003). Condutividade hidráulica de solos de Pernambuco em resposta à condutividade elétrica e RAS da água de irrigação. Revista Brasileira de Engenharia Agrícola e Ambiental, 7, 45-52. https://doi.org/10.1590/S1415 $-43662003000100008$

Gomes, K. R., Amorim, A. V., Ferreira, F. J., Andrade Filho, F. L., Lacerda, C. F., \& Gomes Filho, E. (2011). Respostas de crescimento e fisiologia do milho submetido a estresse salino com diferentes espaçamentos de cultivo. Revista Brasileira de Engenharia Agrícola e Ambiental, 15(4), 365-370. https://doi.org/10.1590/ S1415-43662011000400006

Jacomine, P. K. T. (2005). Origem e evolução dos conceitos e definições de atributos, horizontes diagnósticos e das classes de solos do Sistema Brasileiro de Classificação de Solos. In P. Vidal-Torrado, L. R. F. Alleoni, M. Cooper, A. P. Silva, \& E. J. Cardoso (Eds), Tópicos em ciência do solo (pp. 193-221). Viçosa, MG: Sociedade Brasileira de Ciência do Solo.

Lacerda, C. F., Cambraia, J., Oliva, M. A., \& Ruiz, H. A. (2004). Influência do cálcio sobre o crescimento e solutos em plântulas de sorgo estressadas com cloreto de sódio. Revista Brasileira de Ciência do Solo, 28, 289-295. https://doi.org/10.1590/S0100-06832004000200007

Lepsch, I. (2002). Formação e conservação dos solos. São Paulo, SP: Oficina de Textos.

Lindsay, W. L. (1979). Chemical equilibria in soils. New York, NY: Wiley-Interscience.

Lopes, M. A. C., Muniz, R. V. S., Alves, S. S. V., Ferreira, A. C., Sá, F. V. S., \& Silva, L. A. (2017). Água salina e substratos no crescimento inicial do meloeiro. Irriga, 22(3), 469-484. https://doi.org/10.15809/irriga. 2017v22n3p469-484

Machado, R. M. A., \& Serralheiro, M. P. (2017). Soil Salinity: Effect on Vegetable Crop Growth. Management Practices to Prevent and Mitigate Soil Salinization. Horticulturae, 30(3), 1-13. https://oi.org/10.3390/ horticulturae 3020030 
Miranda, J. R. P., Carvalho, J. G., Santos, D. R., Freire, A. L. O., Bertoni, J. C., Melo, J. R. M., \& Caldas, A. L. (2002). Silício e cloreto de sódio na nutrição mineral e produção de matéria seca de plantas de Moringa (Moringa oleifera, LAM). Revista Brasileira de Ciência do Solo, 26, 957-965. https://doi.org/10.1590/ S0100-06832002000400013

Oliveira, L. B., Ribeiro, M. R., Ferraz, F. B., \& Jacomine, P. K. T. (2003). Classificação de solos Planossólicos do Sertão do Araripe (PE). Revista Brasileira de Ciência do Solo, 27, 685-693. https://doi.org/10.1590/ S0100-06832003000400013

Pereira, F. A. M., Medina, B. F., Gheyi, H. R., \& Etchevers, J. D. (1982). Solos afetados por sais no Nordeste. II. Correlação entre sódio solúvel e intercambiável. Revista Brasileira de Ciência do Solo, 6, 167-170.

Pessoa, L. G. M., Freire, M. B. G. S., Freire, F. J., \& Menezes, D. (2012). Crescimento de cebola irrigada com águas salinas em solos do semiárido de Pernambuco. Revista Brasileira de Ciências Agrárias, 7(3), 527-534. https://doi.org/10.5039/agraria.v7i3a1552

Ribeiro, M. R., Freire, F. J., \& Montenegro, A. A. (2003). Solos halomórficos no Brasil: Ocorrência, gênese, classificação, uso e manejo sustentável. In N. Curi, J. J. Marques, L. R. G. G. Guilherme, J. M. Lima, A. S. Lopes, \& V. H. Alvarez (Eds.), Tópicos em Ciência do Solo (pp. 165-208). Viçosa, MG: Sociedade Brasileira de Ciência do Solo.

Richards, L. (1954). Diagnosis and improvement of saline and alkali soils. Agriculture Handbook 60. Washington, DC: US Department of Agriculture.

Ruiz, H. A. (2005). Incremento da exatidão da análise granulométrica do solo por meio da coleta da suspensão (Silte + Argila). Revista Brasileira de Ciência do Solo, 29, 297-300. https://doi.org/10.1590/S0100-068320 05000200015

Sampaio, E. V. S. B. (1995). Overview of the Brazilian Caatinga. In S. H. Bullock, H. Money, \& E. Medina (Eds.), Seasonally Dry Tropical Forests (pp. 35-63). Cambridge, MA: Cambridge University Press. https://doi.org/10.1017/CBO9780511753398.003

Santos, R. D., Lemos, R. C., Santos, H. G., Ker, J. C., \& Anjos, L. H. C. (2005). Manual de descrição e coleta de solo no campo (5th ed.). Viçosa, MG: Sociedade Brasileira de Ciência do Solo.

Tedesco, M. J., Gianello, C., \& Bissani, C. A. (1995). Análises de solo, plantas e outros materiais (2nd ed.). Porto Alegre, RS: Universidade Federal do Rio Grande do Sul.

Wong, V. N. L., Greene, R. S. B., Dalal, R. C., \& Murphy, B. W. (2010). Soil Carbon Dynamics in Saline and Sodic Soils: A review. Soil Use and Management, 26, 2-11. https://doi.org/10.1111/j.1475-2743. 2009.00251.x

\section{Copyrights}

Copyright for this article is retained by the author(s), with first publication rights granted to the journal.

This is an open-access article distributed under the terms and conditions of the Creative Commons Attribution license (http://creativecommons.org/licenses/by/4.0/). 